\title{
Chondrites isp. Indicating Late Paleozoic Atmospheric Anoxia in Eastern Peninsular India
}

\author{
Biplab Bhattacharya ${ }^{1}$ and Sudipto Banerjee ${ }^{2}$ \\ ${ }^{1}$ Department of Earth Sciences, Indian Institute of Technology Roorkee, Roorkee, Uttarakhand 247667, India \\ ${ }^{2}$ Department of Geology, Hooghly Mohsin College, Chinsurah, Hooghly, West Bengal 712101, India
}

Correspondence should be addressed to Biplab Bhattacharya; bbgeofes@iitr.ac.in

Received 29 August 2013; Accepted 17 November 2013; Published 30 January 2014

Academic Editors: U. Tinivella and G. Ventura

Copyright (C) 2014 B. Bhattacharya and S. Banerjee. This is an open access article distributed under the Creative Commons Attribution License, which permits unrestricted use, distribution, and reproduction in any medium, provided the original work is properly cited.

\begin{abstract}
Rhythmic sandstone-mudstone-coal succession of the Barakar Formation (early Permian) manifests a transition from lower braided-fluvial to upper tide-wave influenced, estuarine setting. Monospecific assemblage of marine trace fossil Chondrites isp. in contemporaneous claystone beds in the upper Barakar succession from two Gondwana basins (namely, the Raniganj Basin and the Talchir Basin) in eastern peninsular India signifies predominant marine incursion during end early Permian. Monospecific Chondrites ichnoassemblage in different sedimentary horizons in geographically wide apart $(\sim 400 \mathrm{~km})$ areas demarcates multiple short-spanned phases of anoxia in eastern India. Such anoxia is interpreted as intermittent falls in oxygen level in an overall decreasing atmospheric oxygenation within the late Paleozoic global oxygen-carbon dioxide fluctuations.
\end{abstract}

\section{Introduction}

Trace fossils provide signatures of animal responses to various ecological controls, including salinity and its fluctuations, sedimentation rate, oxygenation, availability of food, and temperature. Oxygen deficiency is common in deep, quiet water environments, where fine-grained sediments accumulate slowly. In shallower marginal marine conditions, atmospheric oxygen content regionally controls the availability of oxygen near the sediment-water interface. Besides, decomposition of large quantities of terrigenous organic detritus in wave-dominated estuaries may cause localized lowering of oxygen levels near the sediment-water interface [1]. Low oxygen concentration leads to substantial reduction in the size of the trace fossils and their diversity [2], accompanied by dominance of deposit-feeding burrows that maintain an open conduit to the sediment-water interface [3]. Trace fossil assemblage found in such settings includes Chondrites, Zoophycos, Teichichnus, and Trichichnus [2-4]. Monospecific assemblages of Chondrites suggest poorly oxygenated bottom waters [5] and are considered to be associated with prolific marine conditions of deposition $[2,3]$. The tracemaker of Chondrites may be able to live in the aerobic/anoxic interface as a chemosymbiotic organism that pumps methane and hydrogen sulphide from the sediments [6].

The present paper reports the occurrence of Chondrites isp. from the sedimentary successions of the early Permian Barakar Formation (in lower Gondwana Supergroup), exposed along the Kudaposi Nala section in the Talchir Basin and the Khudia Nala section in the Raniganj Basin, eastern peninsular India. Geographic distance between these two areas is $\sim 400 \mathrm{~km}$. This paper describes the occurrence of different ichnospecies of Chondrites from two widely apart Gondwana basins and correlates that with the fluctuations of atmospheric oxygen level during the late Paleozoic period.

\section{Geological Background}

Barakar Formation (early Permian) within the Gondwana sedimentary succession is the main coal-producing horizon in Indian Subcontinent. Earlier studies recorded a braidedmeandering fluvial depositional system with peat-forming mires in the low-lying marshy floodplains that produced thick succession of sandstone-shale-coal cyclothems within the Barakar Formation [7]. Recent sedimentological analyses from multiple Gondwana basisn of India suggested 
strong influence of marine wave and tide on fluvial sedimentation during the deposition of middle-upper Barakar succession [8-10], indicating a fluvio-marine interactive deltaic/estuarine depositional setting. The Barakar Formation in the Raniganj Basin in the Koel-Damodar Valley and the Talchir Basin in the Mahanadi Valley (Figure 1), comprises of thick sandstone-shale-coal deposits (Figure 2) manifesting similar depositional history. The lower parts of the sedimentary successions in both the basins bear thick coal seams and represent braided-fluvial depositional setting (Figure 2).

The studied rocks preserved in both the Kudaposi Nala section, Talchir Basin, and the Khudia Nala section, Raniganj Basin (Figure 1), represent part of the upper Barakar sedimentary succession (Figures 2 and 3). The upper Barakar sedimentary successions of both the Damodar Valley and the Mahanadi Valley have been assigned the age of Kungurian (post-Artinskian) with an approximate time frame of 278$271 \mathrm{Ma}$ [11]. The studied rocks are characterized by thickbedded (1-2.5 $\mathrm{m}$ thickness), coarse-grained, trough crossstratified to plane-laminated sandstone facies (Figures 4(a) and $4(\mathrm{~b})$ ), overlain by $\mathrm{cm}$ thin sandstone-siltstone-claystone alternations facies (Figures 5(a) and 5(b)). Thickness of the sandstone-siltstone-claystone alternation facies varies from $1.5 \mathrm{~m}$ to $4.3 \mathrm{~m}$. The sandstone beds within this facies are characterized by wave ripples and wave-modified ripples, tidal bundles represented by mud-draped foresets, climbing ripples, flaser beddings, bidirectional ripples, mutually opposite cross-strata sets, vertical and lateral accretion of crossstrata sets with prominent reactivation surfaces, and so forth. Each sandstone bed grades upward to a siltstone/claystone. The claystone beds are occasionally very thick (thickness $1-1.8 \mathrm{~m}$ ) and are characterized by abundant Chondrites isp. on the bedding plane. The sandstone/siltstone-claystone heteroliths that underlie and overlie such thick claystone beds are often characterized by sparse to abundant trace fossil associations, dominantly Planolites isp., Thalassinoides isp., and Paleophycus isp., along with abundant plant fossils. The successions show coarsening upward trend with gradual increase in the deposition of sandstone towards top, and finally overlain by a thick-bedded, trough cross-stratified, coarse-grained sandstone facies.

The sedimentary facies architecture closely resembles those described from Barakar sedimentary succession of the Satpura Basin and the Raniganj Basin, respectively $[9,10]$. The sedimentation patterns changed from a basal braided channel to an upper meandering channel system, where rapid migration of the channels and lateral accretion/coalescing of bars led to deposition of thick trough cross-stratified to plane laminated sandstone [8]. Open marine tide and wave influences produced multiple fining upward successions with characteristic sedimentary features and indicate episodic drowning of the fluvial channels by marine water [10]. Dominant fining-upward succession indicates overstepping overbank levees within a meandering fluvial-marine interactive estuarine setting $[12,13]$. A coarsening-upward succession comprising of coarse-grained channel-filling sandstone facies overlies this succession, indicating progradation of the meandering channel system over the estuarine deposits.

\section{Ichnogenus Chondrites Sternberg}

Chondrites Sternberg is considered as an infaunal depositfeeding system [14]. It comprises a regularly branching tunnel system consisting of a small number of master shafts open to the surface, which ramify at depth to form a dendritic network [14-17]. In the present paper, we describe four different species of Chondrites from the Barakar Formation, namely, Chondrites patulus (from Kudaposi Nala), Chondrites targionni (from both Kudaposi Nala and Khudia Nala), Chondrites affinis (from both Kudaposi Nala and Khudia Nala), and Chondrites recurvus (from Khudia Nala). In both the study sections, all the ichnoforms are hosted in finegrained, massive claystone, mostly preserved as epichnial, sand/silt-filled ridges on the claystone bedding surfaces. The following is a description of all the ichnospecies recorded from the two areas under study.

3.1. Ichnospecies Chondrites patulus (Figures 6(a) and 6(b)). These are small, straight, unlined, branching burrow system, preserved on the claystone bedding surfaces. These ichnoforms show filling by fine-grained sandstone/siltstone and characteristically lack spreiten laminae. Offshoots branch out from the main stem on both sides making obtuse angle with the stem. Individual branches are 0.25 to $0.3 \mathrm{~cm}$ wide and $1.2 \mathrm{~cm}$ in length. Offshoots do not show any further branching.

3.2. Ichnospecies Chondrites targionii (Figures 6(b) and 6(c)). This ichnospecies is represented by straight to dendritic, unlined, smooth walled burrow system with few branches, preserved on the claystone bedding surface. Traces are parallel to bedding surface and radiate at an angle varying from low to high angle. Secondary branching is absent. Length of the branches varies between 1.2 and $1.5 \mathrm{~cm}$ and width up to $0.22 \mathrm{~cm}$. Burrow fills are commonly coarser-grained sediments with respect to the host sediments. Spreiten lamellae are characteristically absent.

3.3. Ichnospecies Chondrites affinis (Figures 6(a), 6(b), and $6(c)$ ). These are represented by relatively larger, epirelief, bedding parallel concave tubes. These are preserved within claystone as straight to curved sand/siltstone ridges with locally preserved spreiten lamellae. The tubes are unlined and rarely show branching. Main stem is $4.1-6.5 \mathrm{~cm}$ in length and $0.25 \mathrm{~cm}$ wide with the branches varying in length between $0.4-0.8 \mathrm{~cm}$ and $0.25 \mathrm{~cm}$ in width. Secondary branching is absent. The tubes locally overly other such tubes.

3.4. Ichnospecies Chondrites recurvus (Figures 6(a) and 6(c)). These ichnoforms are represented by short, curved, epirelief traces. Branching intensity is relatively high with respect to other ichnoforms in the study area. The branches are peculiarly curved following the main stem. Length of the main stem is approximately $2.5 \mathrm{~cm}$ whereas the branches are up to $0.4 \mathrm{~cm}$ in length. Locally these traces are not clear due to poor preservation of the off-suits. 


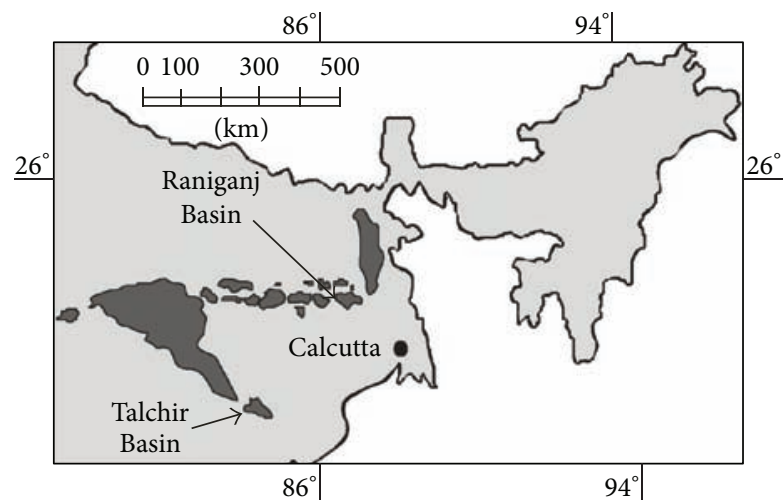

Peninsular Gondwana Basins
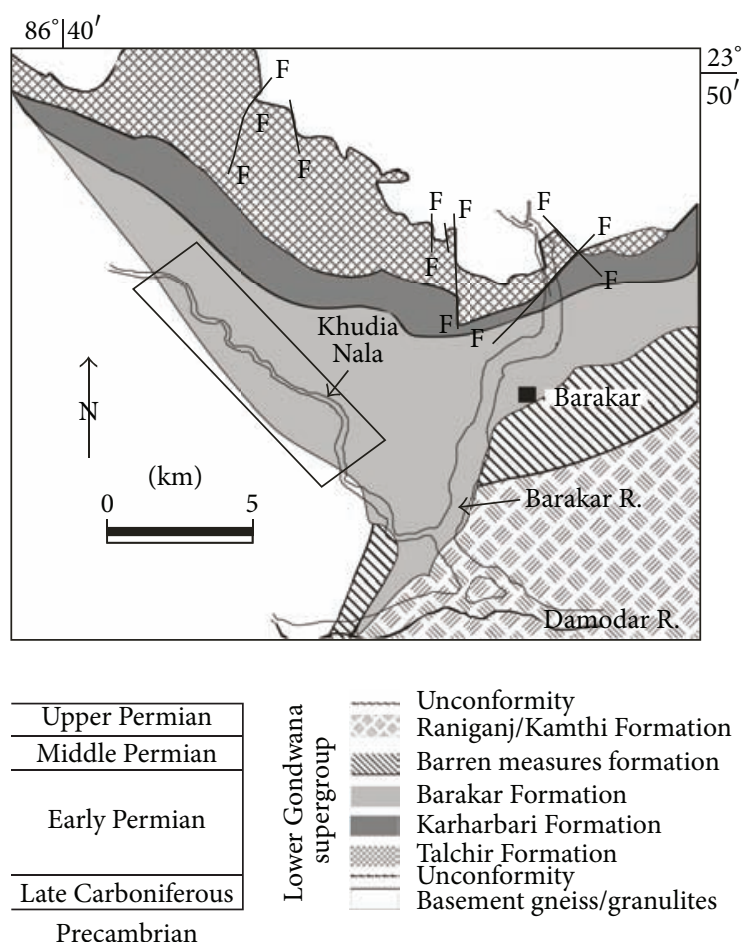

Precambrian

(a)

(b)

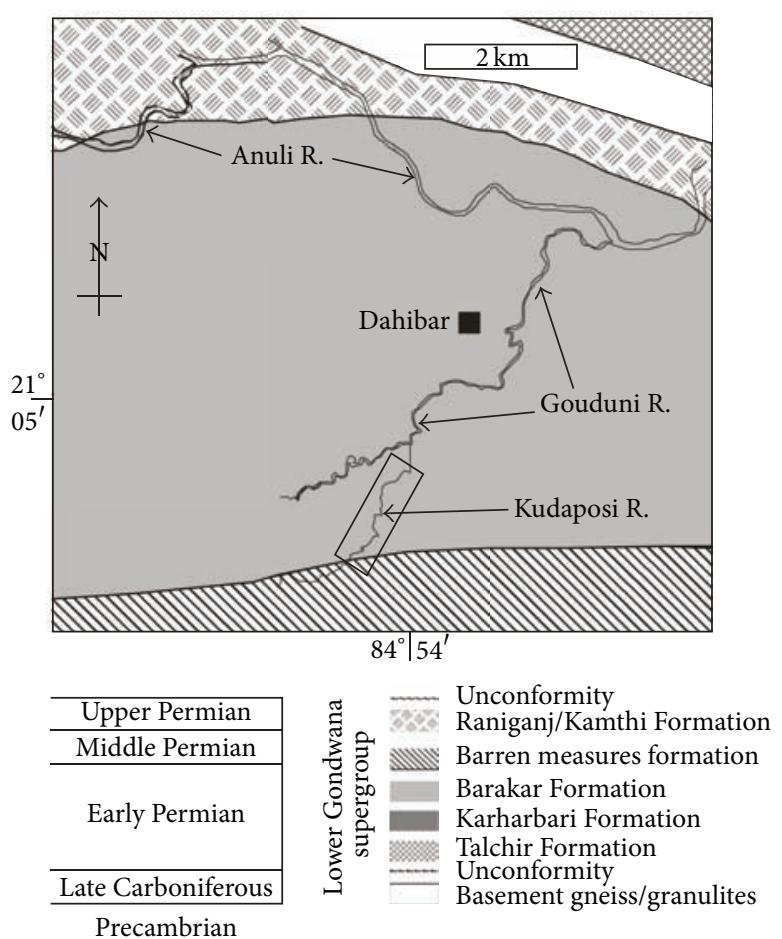

(c)

Figure 1: (a) Map of eastern India showing the distribution of the Gondwana Basins. Note the location of the Raniganj Basin and the Talchir Basin. (b) Geological map of the north-western part of the Raniganj Basin, showing the distribution of different lithounits. (c) Detailed geological map of the central part of the Talchir Basin, showing the distribution of different lithounits. The legend shows the ages of the lithounits. Study areas are shown by rectangles in both the maps ((b) and (c)). 


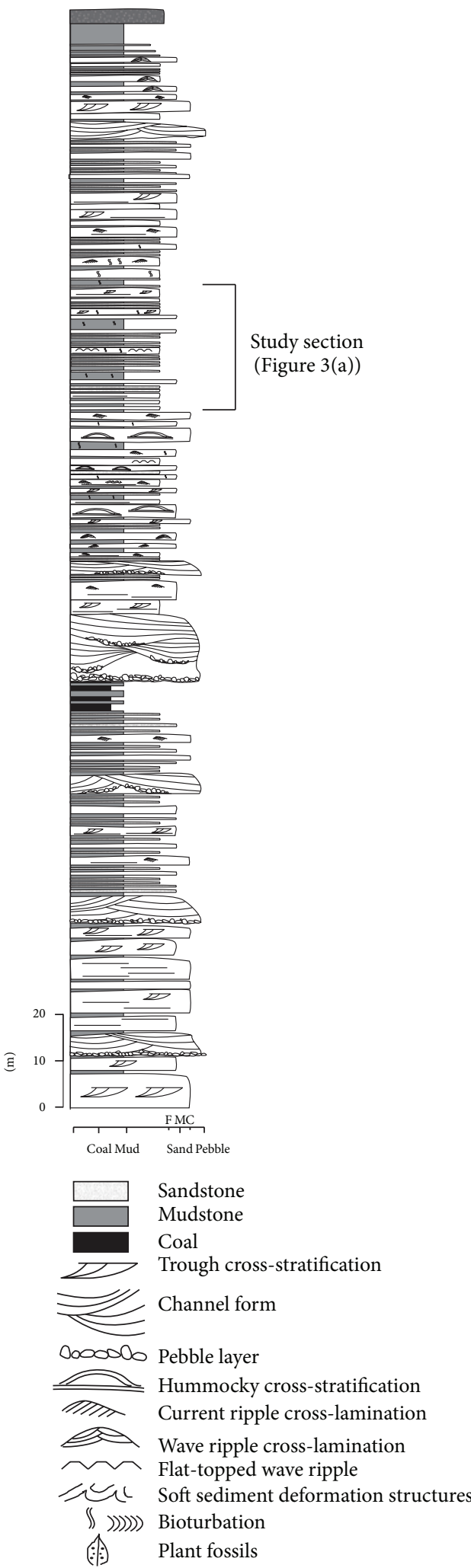

(a)

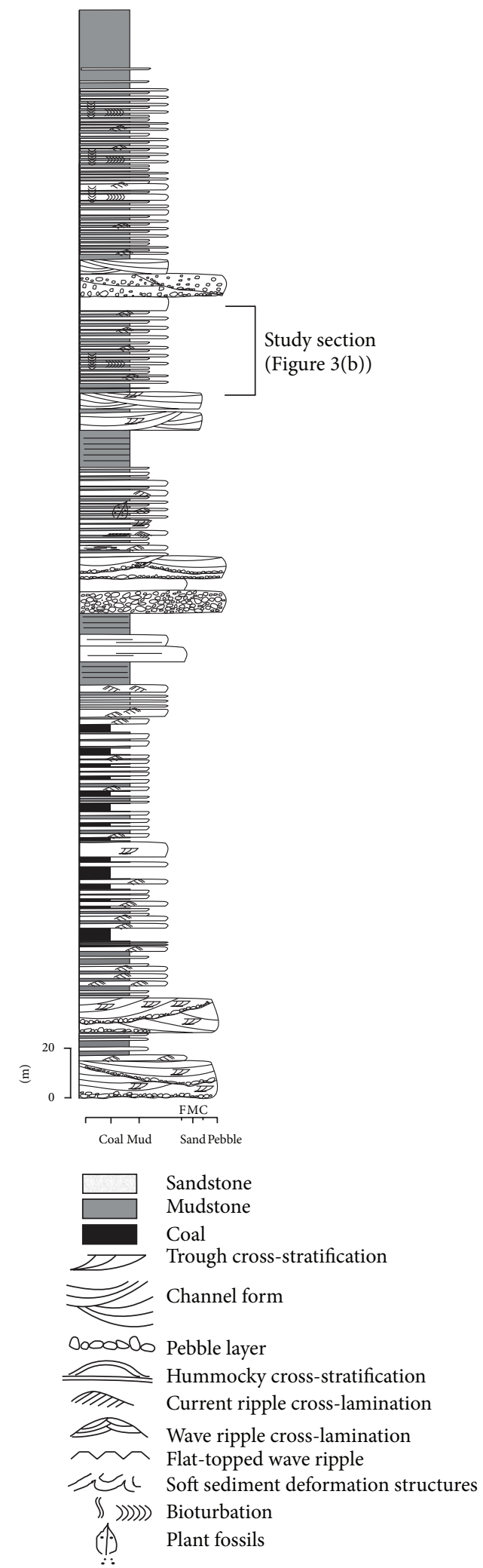

(b)

FIgure 2: Generalized sedimentary logs of the Barakar Formation in (a) Raniganj Basin and (b) Talchir Basin. The study sections are marked and are detailed in Figure 3(a) (Khudia Nala) nad Figure 3(b) (Kudaposi Nala), respectively. 


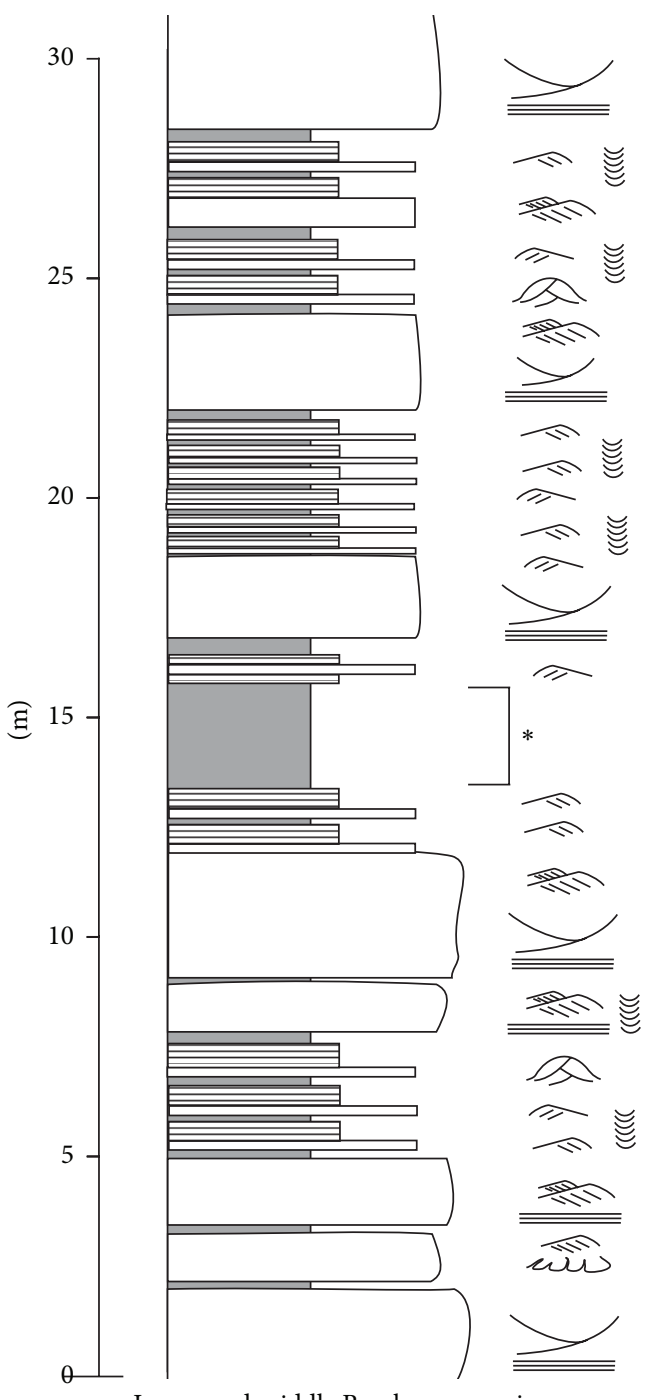

Lower and middle Barakar succession

\begin{tabular}{|c|c|}
\hline & Sandstone \\
\hline & Siltstone \\
\hline & Claystone \\
\hline$\omega$ & Soft-sediment deformation structures \\
\hline (ㄴ) & $\begin{array}{l}\text { Thalassinoides-Paleophycus-Planolites } \\
\text { trace fossil assemblage }\end{array}$ \\
\hline * & Monospecific assemblage of Chondrites isp. \\
\hline & Plane lamination \\
\hline & Trough cross-stratification \\
\hline$\ll$ & Current ripple \\
\hline & Wave ripple \\
\hline$\$$ & Climbing ripple \\
\hline
\end{tabular}

(a) Khudia Nala

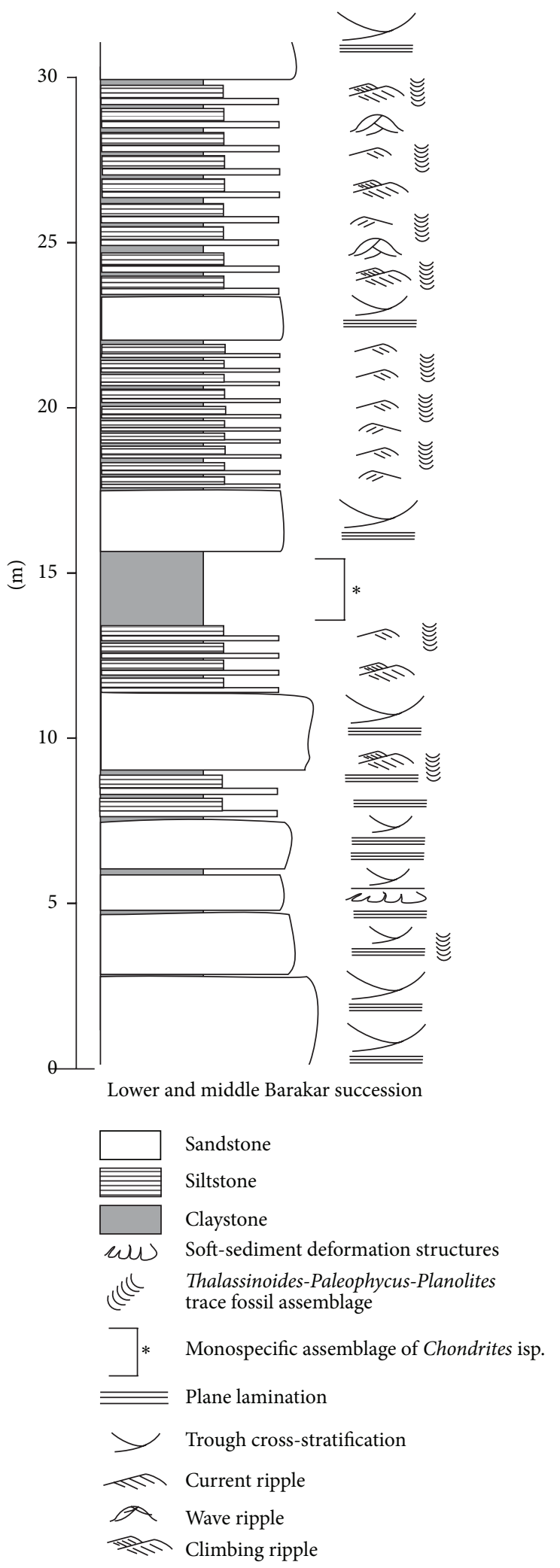

(b) Kudaposi Nala

FIGURE 3: Vertical sedimentary logs of the upper Barakar succession in (a) Khudia Nala, Raniganj Basin, and (b) Kudaposi Nala, Talchir Basin. Note the occurrence of the claystone beds containing monospecific assemblage of Chondrites isp. 


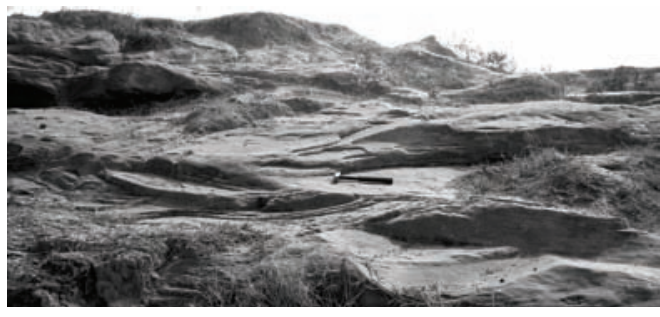

(a)

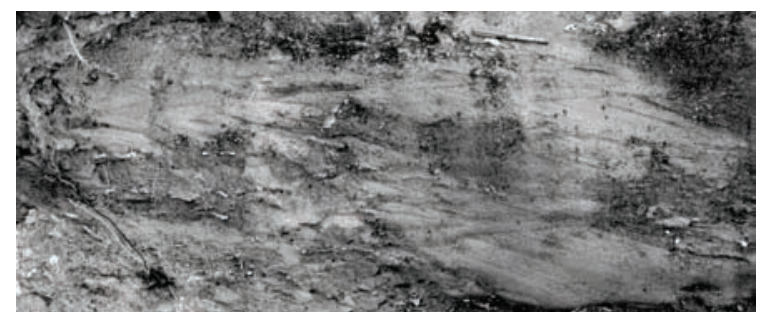

(b)

FIgURE 4: (a) Trough cross-stratified sandstone facies within Barakar Formation, Khudia Nala, Ranjiganj Basin. Length of the hammer is $30.5 \mathrm{~cm}$. (b) Amalgamated sandstone beds showing multiple sets of planar and trough cross-stratification, Barakar Formation, Kudaposi Nala, Talchir Basin. Length of the pen is $14.6 \mathrm{~cm}$.

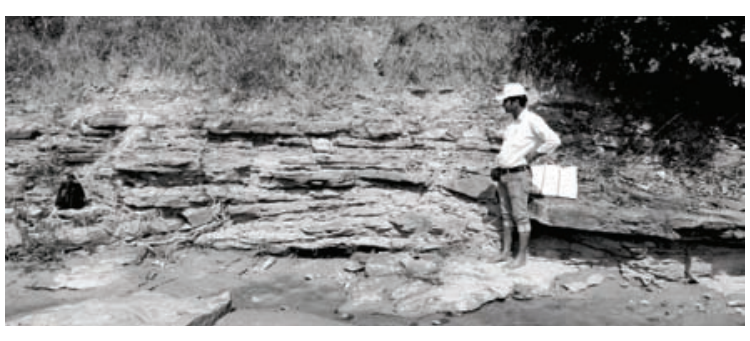

(a)

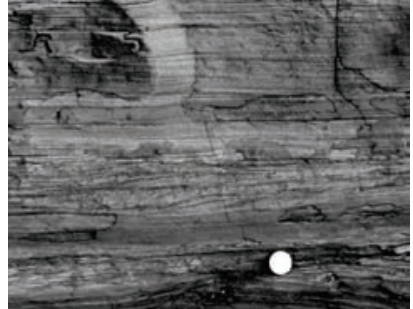

(b)

Figure 5: (a) The sandstone-siltstone-claystone facies exposed in the Kudaposi Nala, Talchir Basin. (b) Details of the sandstone-siltstoneclaystone facies, exposed in the Khudia Nala, Raniganj Basin. Diameter of the coin is $2.3 \mathrm{~cm}$.

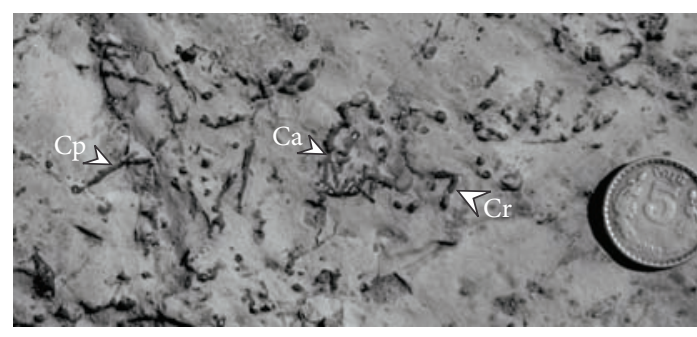

(a)

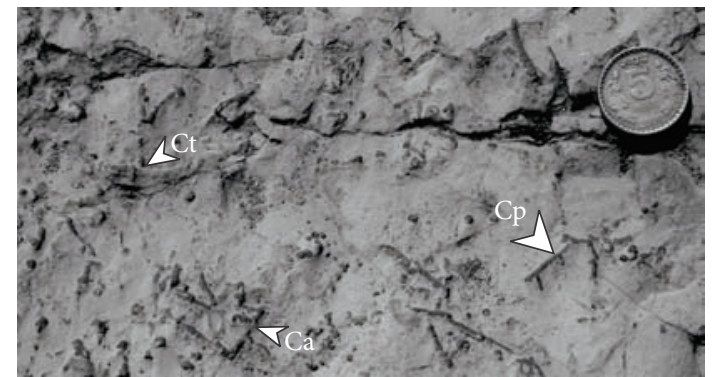

(b)

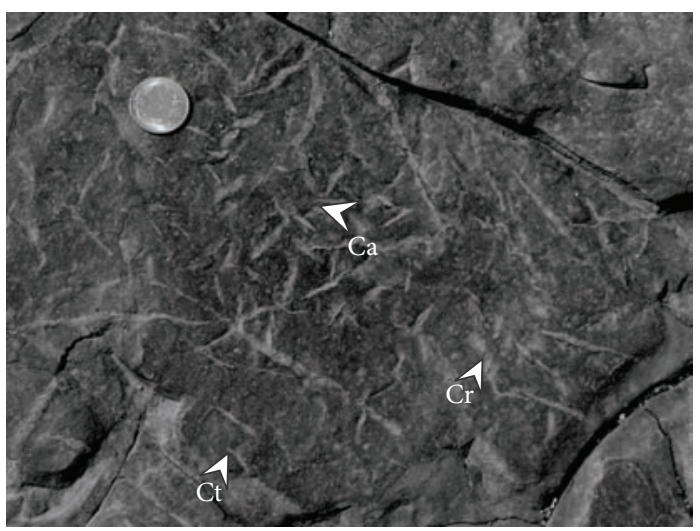

(c)

FIGURE 6: Claystone bedding surfaces within upper Barakar succession, showing associations of Chondrites patulus (Cp), Chondrites targionii (Ct), Chondrites affinis (Ca), and Chondrites recurvus (Cr). (a) and (b) are from Kudaposi Nala, Talchir Basin, and (c) is from Khudia Nala, Raniganj Basin. Diameter of the coin is $2.3 \mathrm{~cm}$ in (a) and (b) and $2.5 \mathrm{~cm}$ in (c). 


\section{Discussion}

The ichnoform Chondrites is considered as an indicator ofpoor oxygenation (dysaerobic-exaerobic) conditions $[5,18-$ 22] and has been described from several late Paleozoic sedimentary successions, including shallow marine argillites, storm-led sediments, and flysch deposits. These three-dimensional, branched, straight to curved, dendritic burrow systems are considered as deposit-feeding traces [14]. These were reinterpreted as complex, agrichnial traces based on their chemosymbiotic activities within predominantly anoxic environment [5]. Polychaete worms are considered as the most likely producers of Chondrites, as they can tolerate oxygendeficient conditions [23-26]. Chondrites-like deposit-feeding burrows with open connections to the sediment-water interface are typical of facies associated with extremely low oxygen levels in interstitial and bottom waters [3].

Estuaries are characterized by numerous ecological stresses on potential trace-making organisms, including fluctuating salinity levels, high water turbidity, rapid sedimentation rates, and low oxygen levels in bottom and interstitial waters. These paleoecological factors control the trace fossil assemblage in estuaries. Trophic generalists are able to adapt their feeding strategy in response to changing environmental controls under brackish-water settings, producing complex burrow morphologies characteristic of marine ecological system [27]. This is the case observed in the estuarine deposits of the late Paleozoic upper Barakar Formation, eastern India. Thick claystone beds within the sandstonesiltstone-claystone alternation facies represent deposition in low-lying, swampy, interdistributary plains. This claystone bears the monospecific assemblage of Chondrites ichnoforms. The overlying and underlying sequence of thin-bedded sandstone-mudstone heteroliths, formed by open marine tide-wave reworkings near the distributary mouth, containing sparse to dense assemblage of Planolites isp., Thalassinoides isp., and Paleophycus isp. The overall ThalassinoidesPlanolites-Chondrites ichnocoenoses is characteristic of estuarine setting.

The Chondrites-bearing claystone beds attest to dominant marine inundations (maximum flooding surface (MFS)) of the estuary, with prevalence of anoxic phases in the ambience. Occurrence of abundant Chondrites ichnoassemblage in multiple narrow but identical sedimentary horizon (claystone) in widely apart geographic locales in eastern peninsular India points to multiple short but predominant anoxic phases in the depositional realm that possibly persisted all over the eastern peninsular India during the end early Permian time. As the overlying and underlying sediments contain plenty of plant fossils and this part of the lithosuccession is devoid of any intermittent coal layers; hence, the possibility of development of low oxygenation due to decomposition of large organic detritus is negated. So, such localized anoxia within the upper Barakar estuarine system can be correlated with fluctuations in the atmospheric oxygen level. Sequential transition from monospecific Chondrites assemblage to a mixed PlanolitesThalassinoides assemblage indicates gradually increasing oxygenation in the ambience $[4,5]$.

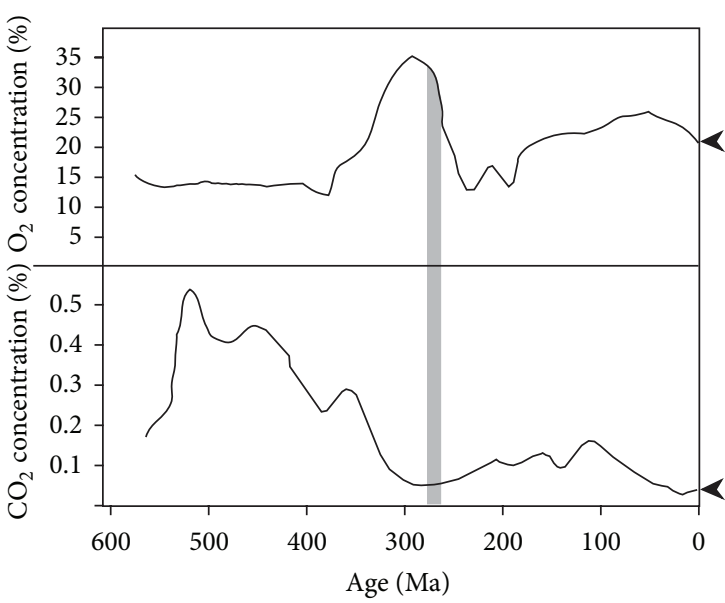

$\square$ Upper Barakar sedimentation (278-271 Ma)
$\square$ Present day concentration

FIGURE 7: Plot showing concentration of $\mathrm{O}_{2}$ and $\mathrm{CO}_{2}$ in the atmosphere during the Phanerozoic time (modified after 31, 32). Note the $\mathrm{O}_{2}$ and $\mathrm{CO}_{2}$ concentrations during the upper Barakar sedimentation $(278-271 \mathrm{Ma})$.

Atmospheric oxygen levels show wide fluctuations during the late Paleozoic time. The oxygen level reached a maximum of $35 \%$ at the end Carboniferous causing enhancement of respiration and gigantism in organisms. This was followed by a significant drop to $15 \%$ at the end Permian leading to mass extinction at the Permo-Triassic boundary. Concomitantly, the carbon dioxide content was raised through the Devonian and Carboniferous, followed by an approximately tenfold reduction during the middle to late Paleozoic time $[28,29]$. During Permian, extensive coal deposition resulted from lesser extent of decomposition of terrestrial plant ecosystems and increased carbon fixation by carbon-reducing organisms. Such disequilibrium between free and stored carbon concentration, extensive oxygen release due to post-Silurian terrestrialization by plants together with changes in continental weathering, organic carbon deposition, and biotic decomposition dramatically modified the atmospheric carbon dioxide and oxygen levels $[28,30]$. The time frame $278-$ $271 \mathrm{Ma}$ (upper Barakar sedimentation) demarcates a steady fall in the atmospheric oxygen level ( 32-25\%) accompanied by a very slow-rising carbon dioxide concentration $(<0.1 \%)$ in global scale (Figure 7) [31, 32]. Record of anoxia demarcated by the Chondrites ichnoassemblage, followed by PlanolitesThalassinoides ichnoassemblages in the overlying and the underlying successions, within the upper Barakar succession in eastern India can be correlated with intermittent drops in oxygen level within a steady phase of decreasing oxygenation within an overall fluctuating atmospheric condition during the early Permian period.

\section{Conclusion}

Postglacial marine invasion of different terrestrial areas within the Gondwanaland during the Permian is well known, 
and the Permian Gondwana sediments from India are not exception to this. Under this framework, in recent times, coal-bearing terrestrial-fluvial sequences of the Barakar Formation are reinterpreted as marine wave-tide influenced deltaic/estuarine deposits, based on different sedimentological and ichnological attributes. Different ichnoforms of the Chondrites isp. are reported for the first time from the upper Barakar succession, which provides further support favouring such marine inundation. Abundance of this typical marine ichnocoenoses in laterally distant areas within several narrow time frames demarcate short phases of anoxia in eastern India during end early Permian period. In this paper, we correlate such anoxic fluctuations with periods of falling-oxygenation within the global oxygen-carbon dioxide fluctuation in the late Paleozoic atmosphere. Record of such atmospheric fluctuation and resultant sediment-organism interaction pattern will be useful in the understanding and the reconstruction of the paleoecological and paleoenvironmental changes within the Permian Gondwanaland-Tethys system.

\section{Conflict of Interests}

The authors declare that there is no conflict of interests regarding the publication of this paper.

\section{Acknowledgments}

Biplab Bhattacharya is grateful to the Department of Science and Technology (DST), Government of India, for financial assistance (FAST TRACK Research Scheme for Young Scientists, no. SR/FTP/ES-170/2010). Authors are grateful to the anonymous reviewers and the editorial board for reviewing this paper.

\section{References}

[1] I. Coates and J. A. McEachern, "The ichnological signature of wave- and river-dominated deltas: Dunvegan and Basal Belly River formations, West-Central Alberta," in Digging Deeper, Finding a Better Bottom Line, B. Wrathall, G. Johnston, A. Arts et al., Eds., Canadian Society of Petroleum Geologists \& Petroleum Society, 1999, Core Conference, paper no. 99-114C.

[2] C. E. Savrda and D. J. Bottjer, "Trace-fossil model for reconstructing oxygenation histories of ancient marine bottom waters: application to upper cretaceous niobrara formation, Colorado," Palaeogeography, Palaeoclimatology, Palaeoecology, vol. 74, no. 1-2, pp. 49-74, 1989.

[3] A. A. Ekdale and T. R. Mason, "Characteristic trace-fossil associations in oxygen-poor sedimentary environments," Geology, vol. 16, no. 8, pp. 720-723, 1988.

[4] C. E. Savrda, "Trace fossils and marine benthic oxygenation," in Trace Fossils-Concepts, Problems, Prospects, W. Miller III, Ed., pp. 149-158, Elsevier, Amsterdam, The Netherlands, 2007.

[5] R. G. Bromley, Trace Fossils-Biology, Taphonomy and Applications, Chapman \& Hall, London, UK, 1996.

[6] A. Seilacher, "Aberrations in bivalve evolution related to photoand chemosymbiosis," Historical Biology, vol. 3, pp. 289-311, 1990.
[7] J. J. Veevers and R. C. Tewari, "Gondwana master basin of Peninsular India between Tethys and the interior of the Gondwanaland Province of Pangea," Geological Society of America Memoirs, vol. 187, pp. 1-73, 1995.

[8] A. Gupta, "Early Permian palaeoenvironment in Damodar valley coalfields, India: an overview," Gondwana Research, vol. 2, no. 2, pp. 149-165, 1999.

[9] S. K. Ghosh, C. Chakraborty, and T. Chakraborty, "Combined tide and wave influence on sedimentation of Lower Gondwana coal measures of central India: Barakar Formation (Permian), Satpura basin," Journal of the Geological Society, vol. 161, no. 1, pp. 117-131, 2004.

[10] B. Bhattacharya, S. Bandyopadhyay, S. Mahapatra, and S. Banerjee, "Record of tidewave influence on the coal-bearing Permian Barakar Formation, Raniganj Basin, India," Sedimentary Geology, vol. 267-268, pp. 25-35, 2012.

[11] G. Mukhopadhyay, S. K. Mukhopadhyay, M. Roychowdhury, and P. K. Parui, "Stratigraphic correlation between different Gondwana Basins of India," Journal of the Geological Society of India, vol. 76, no. 3, pp. 251-266, 2010.

[12] H. G. Reading, Sedimentary Environment and Facies, Blackwell Scientific Publication, 1996.

[13] G. Nichols, Sedimentology and Stratigraphy, Wiley-Blackwell, London, UK, 2nd edition, 2009.

[14] R. G. Osgood Jr., “Trace fossils of the Cincinnati area," Palaeontographica Americana, vol. 6, pp. 281-444, 1970.

[15] F. T. Fürsich, "Ichnogenus rhizocorallium," Paläontologische Zeitschrift, vol. 48, pp. 16-28, 1974.

[16] W. Häntzschel, "Trace fossils and problematica," in Treatise on Invertebrate Paleontology: Part W Miscellanea: Supplement 1, C. Teichert, Ed., p. 269, University of Kansas and Geological Society of America, Boulder, Colo, USA, 2nd edition, 1975.

[17] A. Uchman, "Taxonomy and palaeoecology of flysch trace fossils: the Marnosoarenacea Formation and associated facies (Miocene, Northern Apennines, Italy)," Beringeria, vol. 15, pp. 3-115, 1995.

[18] A. Uchman, K. Bak, and F. J. Rodríguez-Tovar, "Ichnological record of deep-sea palaeoenvironmental changes around the Oceanic Anoxic Event 2 (Cenomanian-Turonian boundary): an example from the Barnasiówka section, Polish Outer Carpathians," Palaeogeography, Palaeoclimatology, Palaeoecology, vol. 262, no. 1-2, pp. 61-71, 2008.

[19] N. B. Carmona, L. A. Buatois, J. J. Ponce, and M. G. Mángano, "Ichnology and sedimentology of a tide-influenced delta, Lower Miocene Chenque Formation, Patagonia, Argentina: tracefossil distribution and response to environmental stresses," Palaeogeography, Palaeoclimatology, Palaeoecology, vol. 273, no. 1-2, pp. 75-86, 2009.

[20] D. Knaust, "Characterisation of a Campanian deep-sea fan system in the Norwegian Sea by means of ichnofabrics," Marine and Petroleum Geology, vol. 26, no. 7, pp. 1199-1211, 2009.

[21] A. Giannetti, "Influence of climate, sea-level changes and tectonics on ichnoassemblages distribution in a carbonatedominated, deep-marine environment (Upper Paleocene, Zumaya section)," Palaeogeography, Palaeoclimatology, Palaeoecology, vol. 285, no. 1-2, pp. 104-118, 2010.

[22] A. Wetzel, R. Tjallingii, and M. G. Wiesner, "Bioturbational structures record environmental changes in the upwelling area off Vietnam (South China Sea) for the last 150,000 years," Palaeogeography, Palaeoclimatology, Palaeoecology, vol. 311, no. 3-4, pp. 256-267, 2011. 
[23] R. G. Bromley and A. A. Ekdale, "Chondrites: a trace fossil indicator of anoxia in sediments," Science, vol. 224, no. 4648, pp. 872-874, 1984.

[24] C. E. Savrda and D. J. Bottjer, "Trace-fossil model for reconstruction of paleo-oxygenation in bottom waters," Geology, vol. 14, no. 1, pp. 3-6, 1986.

[25] J. P. Cummings and D. M. Hodgson, "Assessing controls on the distribution of ichnotaxa in submarine fan environments, the Basque Basin, Northern Spain," Sedimentary Geology, vol. 239, no. 3-4, pp. 162-187, 2011.

[26] M. K. Gingras, J. A. MacEachern, and S. E. Dashtgard, "Process ichnology and the elucidation of physico-chemical stress," Sedimentary Geology, vol. 237, no. 3-4, pp. 115-134, 2011.

[27] J. D. Howard and R. W. Frey, "Characteristic physical and biogenic sedimentary structures in Georgia estuaries," AAPG Bulletin, vol. 57, pp. 1169-1184, 1973.

[28] R. A. Berner, "Atmospheric carbon dioxide levels over phanerozoic time," Science, vol. 249, no. 4975, pp. 1382-1386, 1990.

[29] R. A. Berner, "GEOCARB II: a revised model of atmospheric $\mathrm{CO}_{2}$ over Phanerozoic time," American Journal of Science, vol. 294, no. 1, pp. 56-91, 1994.

[30] H. Visscher, H. Brinkhuis, D. L. Dilcher et al., "The terminal paleozoic fungal event: evidence of terrestrial ecosystem destabilization and collapse," Proceedings of the National Academy of Sciences of the United States of America, vol. 93, no. 5, pp. 21552158, 1996.

[31] R. Dudley, "Atmospheric oxygen, giant Paleozoic insects and the evolution of aerial locomotor performance," Journal of Experimental Biology, vol. 201, no. 8, pp. 1043-1050, 1998.

[32] R. A. Berner, "Atmospheric oxygen over Phanerozoic time," Proceedings of the National Academy of Sciences of the United States of America, vol. 96, no. 20, pp. 10955-10957, 1999. 

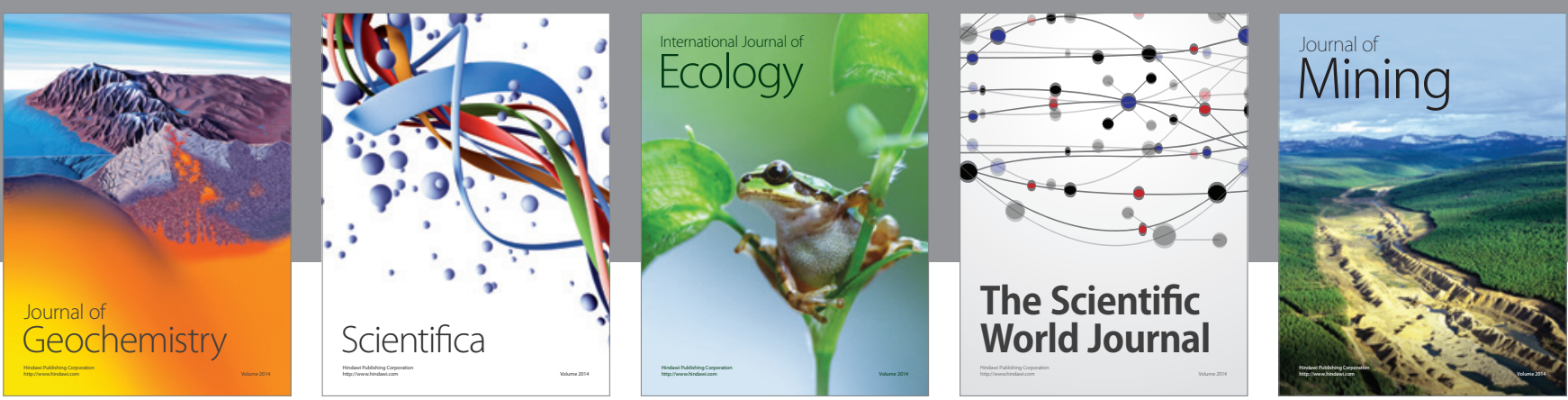

The Scientific World Journal
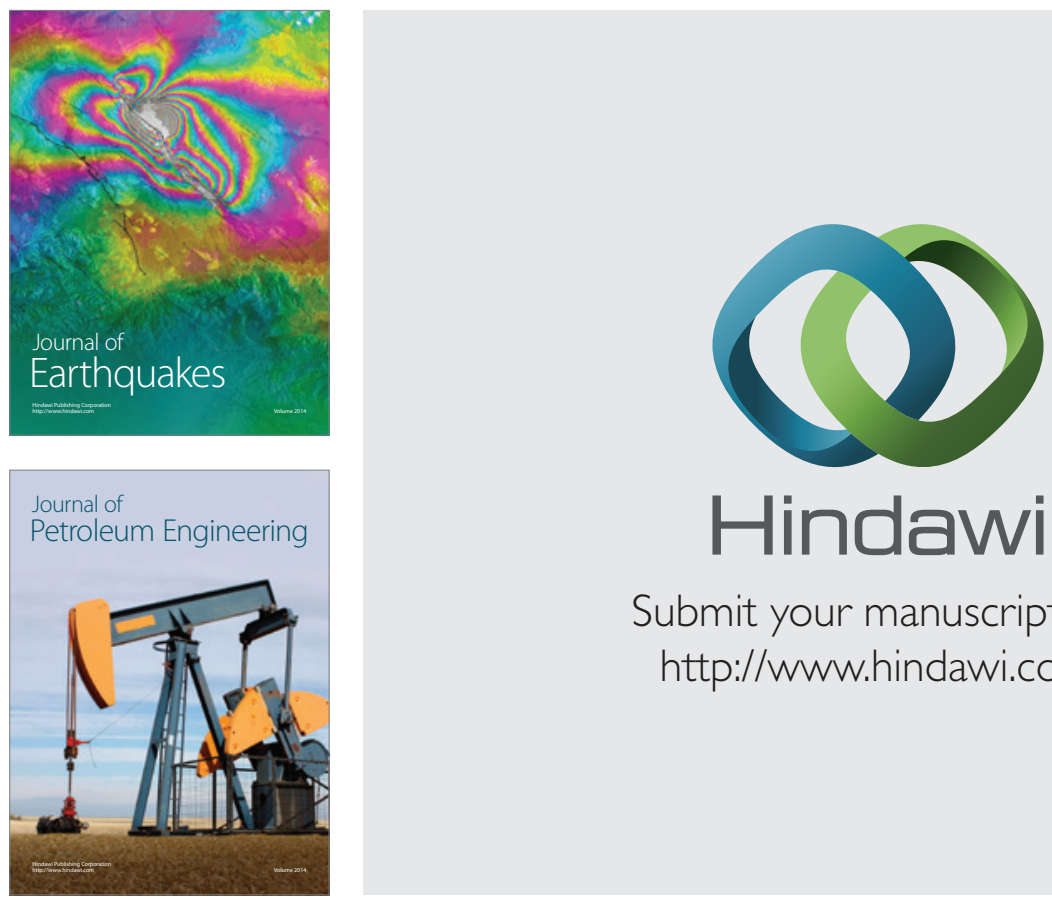

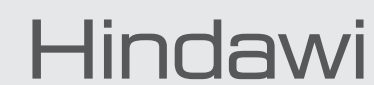

Submit your manuscripts at

http://www.hindawi.com
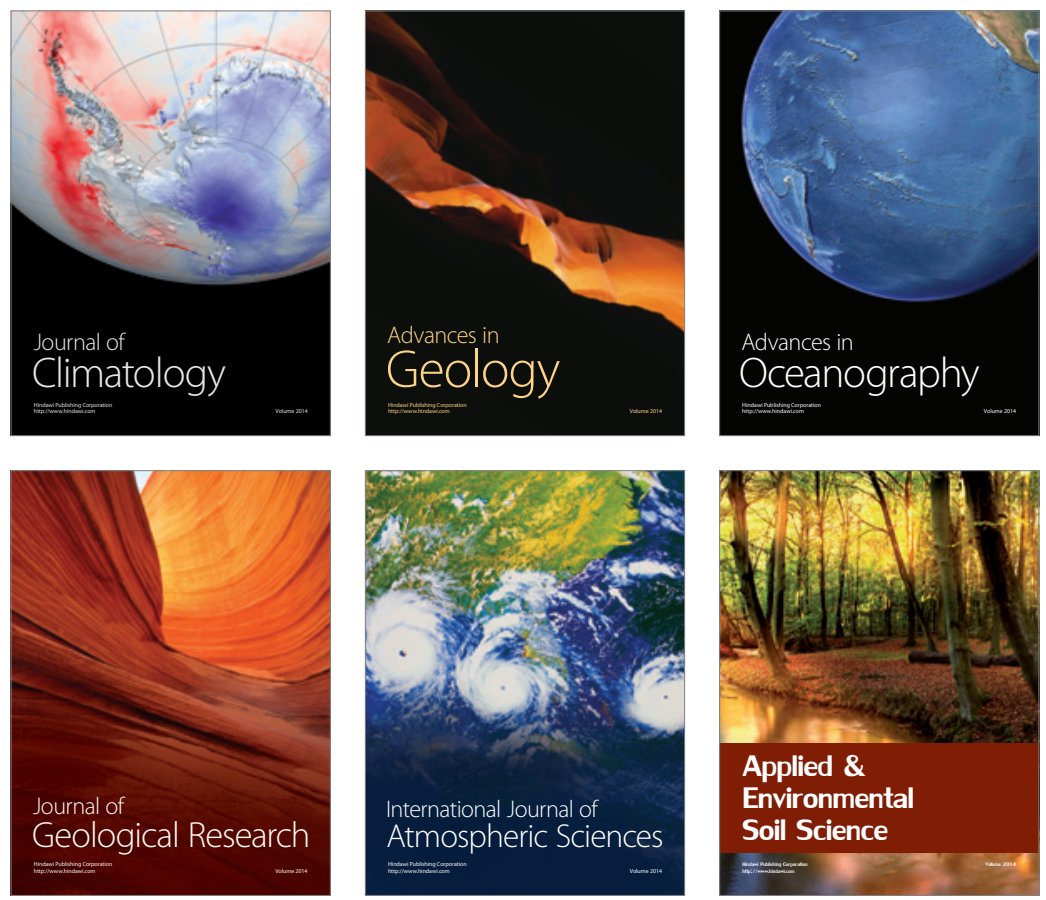
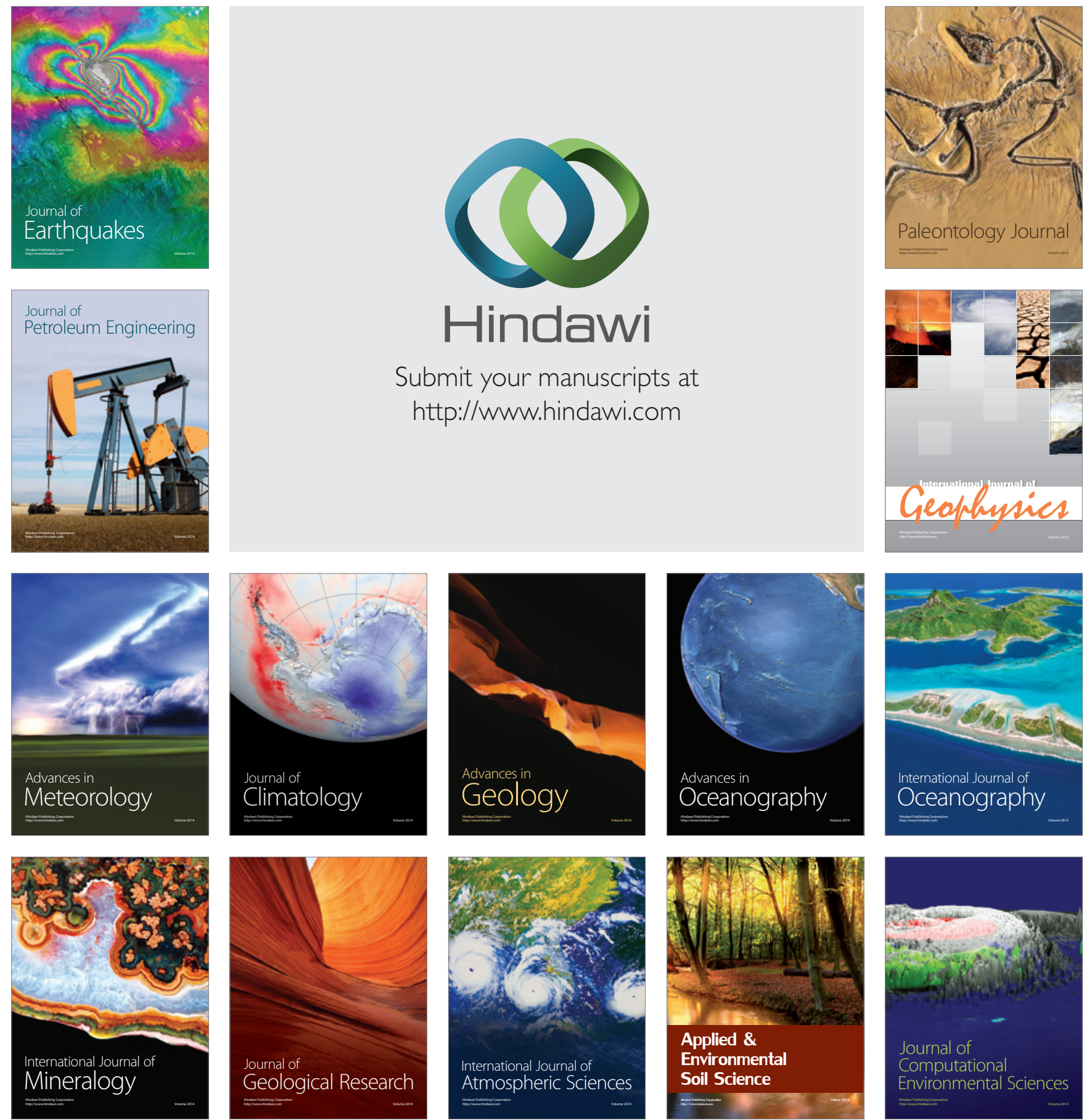